\title{
Speculative Archiving of a Potential Future Literary Award: Embedded Publishing Studies Research
}

\author{
Christina Neuwirth ${ }^{1 *}$ \\ ${ }^{1}$ University of Stirling and University of Glasgow, UNITED KINGDOM \\ *Corresponding Author: christina.neuwirth1@stir.ac.uk \\ Citation: Neuwirth, C. (2019). Speculative Archiving of a Potential Future Literary Award: Embedded \\ Publishing Studies Research, Journal of Cultural Analysis and Social Change, 4(2), 11. \\ https://doi.org/10.20897/jcasc/6355
}

Published: December 11, 2019

\begin{abstract}
Over the course of my doctoral research in publishing studies, I have become curious about the kind of embedded live collaborative study I am undertaking, which is working towards the potential creation of a new literary prize. This article will add to existing scholarship by examining how research can be conceived of as an active part of evidence-based prize creation. To do so, it will draw on feminist research methodology and record formation scholarship, and examine how other awards and literary organisations conceptualise their archives. The article will then present the original findings of the study, beginning with the conceptualisation of the researcher as inhabiting three distinct roles, moving on to modelling the relationship between the researcher and the prize project, concluding with an exploration of these relationships through autoethnographic observations and semi-structured interviews. The article will conclude asserting what these findings mean for this kind of live award scholarship.
\end{abstract}

Keywords: publishing, archive, live research, autoethnography, awards and prizes

\begin{abstract}
Interviewer: I know that we don't have much longer, and this is kind of a question out of left field but it interests me; so, because you were there in that first conversation about this group and the prize and you've witnessed it kind of change, I wondered whether you feel comfortable speaking a little bit about the relationship of the PhD research to the wider project, and how you have witnessed that changing from the first discussion of having a PhD about this to-
\end{abstract}

Jenni Calder: Um

Interviewer: I know it's weird because I'm here

Jenni Calder: (laughs)

(Calder, 2018)

\section{INTRODUCTION}

The above is a quote from an interview conducted to examine gender equality issues in contemporary Scottish writing and publishing. In this interview, I wanted to find out what the impact of having a researcher involved in the prize creation process had been like. I asked the question directly, but perceived hesitation in the interviewee, and chose to break the tension by referring overtly to the discomfort and awkwardness of inhabiting both a position as 'the researcher who is currently conducting this interview' as well as 'the researcher who has been involved in the prize creation process'. 
Over the course of my doctoral research in publishing studies, I have become curious about the kind of embedded live collaborative study I am undertaking, which is working towards the potential creation of a new literary prize. James F. English has described cultural prizes as ubiquitous (English, 2002: 109), and Claire Squires has shown cultural prizes, specifically literary prizes, to be a 'fertile area of study' (Squires, 2004: 46), but their examinations of prizes do not involve direct active involvement in the creation stage of a literary award. While not concerned with the creation of a new award, Marsden and Squires' article in this special issue presents findings of embedded research 'inside' an established set of literary prizes (Marsden and Squires, 2019). This article will add to existing scholarship by examining how research can be conceived of as an active part of evidence-based prize creation. Fundamentally, this article's discussion of archives and positionality is a vehicle to reflect on how to understand collaboration between present and future; creation and legacy.

What historic and scholarly evidence is there that a prize for Scottish women writers may be needed? Glenda Norquay describes the history of women's writing in Scotland as 'a story both of bold declarations of self and of the, at times, secret and strategic infiltrations of walled areas of literary production' (Norquay, 2012: 1). Borrowing Norquay's words above, the purpose of my doctoral research project is to examine whether a literary prize could be an effective tool for the 'strategic infiltration of walled areas of literary production'. While histories of Scottish women's writing published over the past 25 years have pointed out and addressed the lack of historic representation of women writers in Scottish literature (Christianson and Lumsden, 2000a; Gifford and McMillan, 1997a; Norquay, 2012b), they also share a cautious optimism for better representation in contemporary literature. Gifford and McMillan write that '[ $\mathrm{h}]$ istories of Scottish literature have tended in recent years to include more women' (Gifford and McMillan, 1997b: ix) and Norquay points out the 'publication of work by a range of Scottish women writers since the 1980s, the appearance of several histories of writing by women as well as a number of critical studies that explore gender dynamics' (Norquay, 2012a: 2). Lumsden and Christianson problematise the essentialising of nationhood and gender within these histories: "Several of the writers here (...) resist being labelled in terms of their nationality or gender, suggesting that to them such categories are limiting" (Christianson and Lumsden, 2000b: 3). Within book history and publishing studies, Stevie Marsden's analysis of the Saltire Society Book of the Year and First Book of the Year ${ }^{1}$ winners, shortlists and submissions between 1988-2014 shows that, 'despite the fact that critics argued that there was a change in tide in the late 1980s and early 1990s regarding the gender balance in Scottish literature more broadly, this analysis suggests that Scotland's literary culture, and in turn, book award culture, was dominated by men' (Marsden, 2019: 62). My own work has also evidenced that contemporary book reviewing in Scotland privileges male reviewers and male authors (Christina Neuwirth, 2018).

As these examples show, gender inequality in Scottish writing and publishing is a persistent issue; the creation of a new prize to address this, and the opportunity for live embedded research this presents, is an under-researched area. To address this, this article will first introduce conceptual frameworks, drawing on feminist research methodology. As this methodology encourages and requires reflexivity on the part of the researcher, this article will then present the original findings of the study, beginning with a reflection of myself as a researcher inhabiting three distinct roles. Continuing in this reflexive mode, possible models of the relationship between the researcher and the prize project will be presented, before concluding with an exploration of these relationships through autoethnographic observations and semi-structured interviews. It will then give insight into the intersection of archives and literary prize scholarship, drawing on how literary organisations and awards conceptualise and commodify their archives, followed by an exploration of record formation theory and futurity in archive scholarship. The article will conclude asserting what these findings mean for this kind of live award scholarship, and define its key finding of the unique positionality of a 'speculative archivist.'

\section{CONCEPTUAL FRAMEWORK: FEMINIST RESEARCH METHODS AND PRAXIS}

This article takes an explicitly feminist stance, as necessitated by a project concerned with gender equality. Feminist research methodology defines the researcher not as an outsider but as directly, politically involved in the research process. Sharlene Nagy Hesse-Biber describes feminist research as follows:

From data collection to data analysis and interpretation, the process by which feminist researchers conduct their research projects - feminist research praxis - centralizes the relationship between the researcher and researched to balance differing levels of power and authority. Researchers practice reflexivity, a process by which they recognize, examine, and understand how their social background, location, and assumptions can influence the research. (...) Reflexivity is a way for researchers to account

1 The Saltire Society describes its suite of literary awards as "Scotland's most prestigious annual book awards" ('Literary Awards', n.d.) 
for their personal biases and examine the effects that these biases may have on the data produced. (Hesse-Biber, 2013: 3)

Introducing the development of feminist research, Hesse-Biber draws on feminist standpoint epistemology (Harding, 1993; Smith, 1990, cited in Hesse-Biber 2013: 6), which 'is rooted in the shared Marxist and Hegelian idea that an individual's material and lived experience structures his or her understanding of his or her social environment' (Hesse-Biber, 2013: 6). Elsewhere, Hesse-Biber suggests that feminist in-depth interviewing involves reflecting on 'the various ways [the researcher's] social position affects the way [they] observe and perceive others' (Hesse-Biber, 2007: 131). This project therefore therefore foregrounds the individual lived experiences of the researcher and the researched, and how these structure our understanding of our social environment. It practices reflexivity, in particular of the biases and positions an insider brings to the research of their own community (Barton, 2011; Oakley, 1981). I am a woman writer based in Scotland, researching gender equality in contemporary writing and publishing in Scotland; necessarily, my experiences as a writer - before and during this PhD project will therefore impact my perspective, and may become data (cf. Barton, 2011: 432).

The subject of my research has direct, political relevance to me. This is also the case for my interviewees, who are, like me, women working in the Scottish literary sector. Ann Oakley describes the shift in how interviewing is conceptualised through this direct relationship: interviewing changes 'from being a data-collecting instrument for researchers to being a data-collecting instrument for those whose lives are being researched' (Oakley, 1981: 49). I am a participant of the group whose lives are being researched; yet I am also the researcher who is conducting the data collection which in turn will become an instrument to provide evidence for the group I am researching.

\section{CONTEXT AND THE PROJECT}

The research project which forms the basis of this article is a collaborative doctoral research project in publishing studies, examining gender equality in contemporary Scottish writing and publishing, with a view to advising on the creation of a potential future literary prize. I work in close consultation with a group of women working in the Scottish literary industry. My research project is inextricably connected to the work of this group. To begin to tease out the relationship, it is helpful to examine the various ways in which the group defines itself. In interview, group members have referred to themselves as a 'group of activists working within the community' (Armstrong, 2018), or a women's prize project which they were 'working with' (McDowell, 2018) or 'invited [...] to take part [in]'(Oliver, 2018). It was also referred to as a 'group to discuss these issues and look at what we could do' (Shah, 2018), 'the group' (Moir, 2018) and 'the working group' (Squires, 2018). This difference in selfidentification points at one of the key shifts within the group's purpose; the group was initially set up following a suggestion by Judy Moir, a literary agent, during an International Women's Day celebration in $2016 .^{2}$ Moir proposed that there might be a prize for women writers in Scotland (Armstrong, 2018; Calder, 2018; Shah, 2018). In interview, Moir said, recalling this day:

I was aware at that time the Bailey's, that's the former Orange Prize, longlist had just been announced and not a single Scot on it. Maybe Ali Smith was on it, but no-one else. (...) And so I found myself suggesting, you know, do you think it would be a good idea to have a literary prize or several prizes for women in Scotland. All these heads just sort of turned around and, 'Yes, Judy, do something about it!' (Moir, 2018)

Jenni Calder, who was present on this day, said in interview: "I think the feeling was that something was needed to support and promote Scottish women writers, and a prize is something very specific; everybody understands what it is, and that seemed like a good place to start" (Calder, 2018).

Members of the group then secured funding from the Arts and Humanities Research Council (AHRC) and Scottish Graduate School for Arts and Humanities (SGSAH) for a doctoral research project which would examine gender equality in contemporary Scottish writing and publishing (Squires, Reeder, Armstrong, and Shah, 2017). ${ }^{3}$ This led to my appointment as that doctoral researcher, under a Creative Economies Studentship. My involvement prompted a shift in the focus of the group, who were no longer working solely to set up a prize, as the evidence basis for the prize was now within the remit of the doctoral research project. Rather than going ahead with the prize creation, the group is now waiting on advice on how a potential new prize should be set up, and indeed whether it should be set up at all. My doctoral research project, which will give this advice in its concluding chapter, will not be concluded before December 2020. In its first online statement from August 2018, the group, whose

\footnotetext{
2 This event was run by Scottish PEN (the Scottish centre of PEN International) and IASH (the Institute for Advanced Studies in the Humanities at the University of Edinburgh).

3 The research partners involved are University of Stirling, University of Glasgow and Scottish Book Trust.
} 
name is now ROAR (Represent, Object, Advocate, Rewrite) describes itself as 'a group working to combat inequality in Scottish writing and publishing' founded in 2016 (Reid, 2018). The short biography of the group does not refer to the potential for a new literary prize. When referring to the acronym ROAR, I will henceforth call the group 'the advocacy group'. This is not to shy away from specificity, but to ensure other researchers working in this type of research model will find the visualisations applicable.

According to SGSAH guidance, the aim of Creative Economies Studentships is 'to connect HEIs, organisations and a $\mathrm{PhD}$ researcher on a project of mutual benefit to all involved. They present an opportunity to work on a fascinating research project, make connections with industry and access resources and expertise not normally available within a PhD' ('Scottish Graduate School for Arts \& Humanities', n.d.). The projects encompassed in this run of Creative Economies Studentships were described by SGSAH as 'fulfilling a research need already noted by an organisation in the sector,' ('Scottish Graduate School for Arts \& Humanities', n.d.) implying the direct usefulness of this research to a question or a gap already identified by the sector. The original funding application for this particular project has proven to be a useful document for gaining an insight into the initial plans and considerations that led to this research. The application says that this project will 'develop a project plan for the implementation and analysis of a women's writing prize in Scotland, and an associated suite of activities (...)' (Squires et al., 2017: 4). As this article will show, the plans set out by the collaboration partners and by the funders in these two documents are not exhaustive and do not encompass the broad range of relationships inherent in the project. The modelling of the shifting relationships between researcher, advocacy group and the prize project, and the understanding of the added temporal dimension embodied in the role of 'speculative archivist' are vital to the project's traversing of academic, institutional, political and personal priorities and the responsibility for documents created throughout the project. While this is important new knowledge for the field of publishing studies and the modes of embedded research, a key application of these findings is also seen in the funding of new collaborative doctoral projects, to facilitate deeper understanding of potential conflicts of discourse and epistemology.

\section{INSIDERS AND OUTSIDERS}

Feminist scholarship has reflected on the difficulties and opportunities of researching women as a woman (Oakley, 1981) and researching one's own community (Barton, 2011), and teased out complications of these perspectives where research participants share some characteristics in common with the researcher, while occupying a position of power which reverses the power imbalance between researcher and researched in favour of the researched (Puwar, 1997). The descriptive reflection that follows, illustrated by Venn diagrams, traverses my position as insider and outsider in my research, and uncovers insufficiency in these terms as they fail to encompass a temporal dimension of positionality. This draws on reflective notes taken throughout my research process.

\section{Role 1: Participant}

Firstly, I am a participant. I am an active member of the Scottish literary landscape and bring a variety of perspectives on this field to my research and to the considerations around the new prize. I first came to Scotland in 2013 to pursue a Masters degree in Creative Writing at University of Edinburgh, during which time I began working as a bookseller and programming and performing at live literature events. As of April 2019, I have had a novella and several short stories published in print, as well as a number of creative and journalistic non-fiction pieces in print and online. I have been a mentee of a writing development project, given paid and unpaid writing performances, chaired and organised literary events, and participated actively in informal and formal literary networking. I therefore bring my own experiences as a woman writing in Scotland from a range of perspectives to my research, which will become part of my research as anecdotal evidence.

\section{Role 2: Advocate}

Secondly, as well as being an active participant in the literary field I am investigating, I am also an active participant in the advocacy group ROAR, feeding my research findings back to the group as they inform their present and future activities. However, as a researcher, I also use these meetings as sites of observation. In many of my meetings with the advocacy group I am keenly aware of my active participation and my observational role, leading to a double consciousness as I experience decision-making while also playing a part in it.

\section{Role 3: Speculative Archivist}

Thirdly, I see my role as that of a 'speculative archivist'. What I mean by this is that I am aware of the potential longevity of some of the documents I create or have access to. My private note taking, conference papers, and briefing papers for the group are a record of and a contribution to the thought processes that may lead to the creation of a new prize, and as such these documents have a potential to be valuable to researchers in the future who may try to reconstruct the group's motivation. However, since the doctoral research project was set up to 


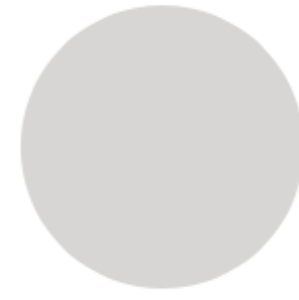

Advocacy group

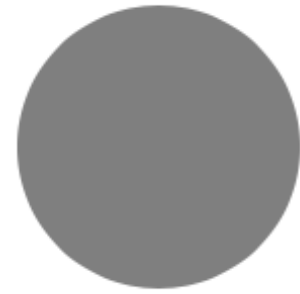

Research project

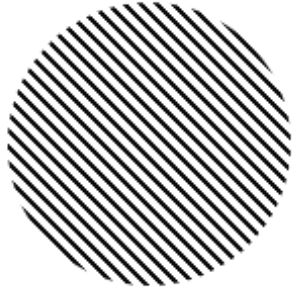

Women's prize project

Figure 1. Components of the Collaboration Model

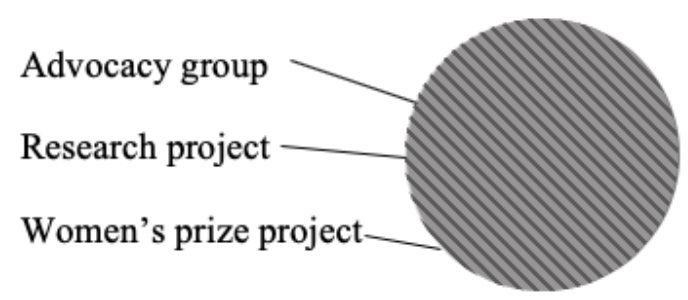

Figure 2. Collaboration Model I

advise on the creation of this new prize, it is not yet certain whether the prize will come into existence - hence the 'speculative' part of my archivist role. I will explore this role throughout the rest of this article, and pin down a definition for it in the article's conclusion.

This triple consciousness becomes particularly apparent during my interaction with the advocacy group. One of my roles is to take minutes at the advocacy group meetings. The purpose of these is to inform the next meeting and be useful to group members who were unable to attend. While taking notes at a meeting I am not simply taking notes at a meeting; I am actively participating in a variety of discourses and creating a document with a variety of purposes. These notes may feed into the creation of a prize, form part of my broader research project, and they may be subject to future scrutiny. If the prize comes to be, the minutes of the group meetings would also be a valuable document to show the history of this prize. The transcripts of my semi-structured interviews also capture information about what the prize might be, so these perspectives captured in a moment in time may also be interesting to a future archive to show what our aims and ideas were for the creation of this prize. Illustrating the types of documents which may be used by future researchers to reconstruct the history of a prize, Marsden refers to using archives held at the National Library of Scotland in a study of the Saltire Society Literary Awards. These archives hold 'several different kinds of documentation, such as hand-written letters, press releases, newspaper articles and faxed documents' (Marsden, 2016: 35). Whenever I become aware of the existence of such documentation relating to our potential future prize, or when I contribute or am wholly responsible for the creation of such a document myself, I think of a future researcher in the National Library of Scotland looking for this information.

\section{MODELLING RELATIONAL POSITIONS}

How do my research project and the advocacy group project overlap and interrelate, and where does the prize fit in? I have come to see this in three distinct ways (see Figure 1).

When I first began this project I saw it as three entirely overlapping circles in a Venn diagram. The research project and the women's prize project were one and the same; my research would steer the direction of the group, and I would effectively project-manage the collection of evidence for and eventual set-up of a new prize. This echoes the plan set out in the funding application, which said that the researcher involved in this project would 'develop, implement and evaluate a programme of activities and advocacy around women writers and women's writing in Scotland (...)' (Squires et al., 2017: 4). This is illustrated by Figure 2.

However, as the project moved on, I began to perceive my research as part of a larger project as part of the women's prize group, which was shifting its focus into broader advocacy (partially outsourcing the evidence creation and investigation of gender inequality to me as the researcher). I also began perceiving the prize as only a portion of the scope of my project.

Figure 3 shows one project sitting within another project, with an implication of the broadening scope of both the group and the research project. The advocacy group defines the potential new prize loosely as one or several 


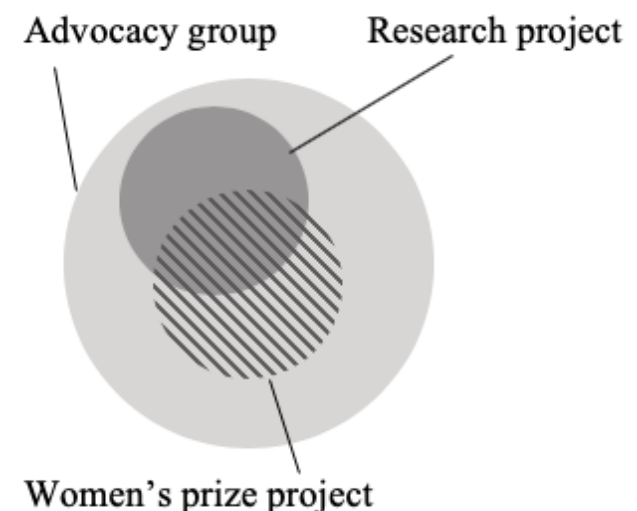

Figure 3. Collaboration Model II

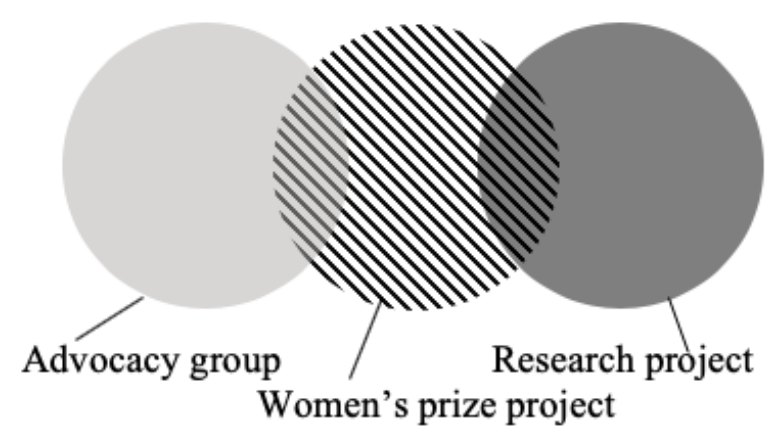

Figure 4. Collaboration model III

prizes, but has not as yet narrowed down what genre the prize would be for, or at what stage of a writer's career it would be awarded. These and all other additional elements of the prize await advice based on the finished research project. Advocacy group meetings form part of the process for investigating what the issues are, yet there are many moments where the conversation is brought back to awaiting results of the research, which situates the group outside that process; that is to say, in these moments the research project is seen as a separate process from the advocacy group project.

As described in the Context section above, there was a key shift in the focus of the advocacy group. Interviewees described this shift by charting the development of the group's aims: 'it just kind of got going from [the call for a women's prize] and it's now developed into something which is much more ambitious in a way, more broadly based' (Calder, 2018) and as 'moving away from this just being about a women's prize it's now (...) a group of activists' (Armstrong, 2018). The prize project's instigator Moir said: 'it's been really slow to get going and that's great, it's been very consultative, and it's great that you're involved too, but we need to ... firm things up a bit' (Moir, 2018). These quotes indicate that the advocacy group's focus has changed and broadened as a result of the development of the research project. However, there is also an indication that the prize has been put on hold, and that the scope and length of the investigation through the research project has slowed down the firming up of what the prize is intended to do, or indeed whether there should be a prize at all.

Now in the second year of the project, I have shifted again to understand the project as existing alongside and partially overlapping with the advocacy group, with the prize existing in the overlapping area of the two circles, but also in an invisible space outside the circles - my research, and indeed the work of the advocacy group, are not the only factors or groups that could potentially lead to a new prize being set up. As a 'speculative archivist' I also record activities of the advocacy group in which I am not actively involved; the scope of the advocacy group's activities therefore goes beyond the scope of my doctoral research project. This overlapping relationship is illustrated by Figure 4.

These diagrams of the projects are useful for my own growing understanding of the complex overlapping relationships at play and how they connect to the prize that may or may not come into existence. In modelling the shifting relationship between myself, the group, and the prize project, the diagrams above lack a temporal dimension. 


\section{ARCHIVES IN PUBLISHING STUDIES}

Before turning to draw on record formation scholarship, however, it is important to examine how archives have been thought of in relation to publishing and literary prizes. After all, the disciplinary background of this study is publishing and book history, and if the present can be historicised, as science fiction studies suggest, as 'the past of a future-yet-to-be' (Hollinger, 2010: 30), then contemporary publishing of the present carries within it potentiality to becoming book history of the future. For example, the Man Booker Prize archive allows for scholarly and journalistic reconstruction. Oxford Brookes University's acquisition of the Man Booker archive in 2003 was itself the subject of a news article. The introduction to this article emphasises the physical space housing the archive, and the material artefacts within it:

Turn right into the ground floor of Oxford Brookes's Headington library and you come to a small, nondescript side room. Not so long ago this used to be someone's - though no one can remember quite whose - office, but now it's home to 115 cardboard boxes. Or, to be more precise, 115 acid-free cardboard boxes. For this room now houses the entire archive of the Man Booker prize, making it home to one of the most important collections in modern British and Commonwealth publishing. (Crace, 2003)

The article continues to describe that the archive could have been sold for a large amount of money but was given to Oxford Brookes for free (or, the article suggests, in exchange for an honorary doctorate). Squires is quoted in the article saying how useful the archive will be to future scholars:

Claire Squires, senior lecturer in publishing at Oxford Brookes, can scarcely wait to get her mitts on the archive. 'It's a brilliant mix of the everyday and the academic,' she says. 'It will provide wonderful material on how we promote and create culture, how we decide whether a book is good or bad and how literary reputations are made. It will also chart the globalisation of the publishing industry, with the demise of the independents and the growth of the large corporations.' (Crace, 2003)

More recently, in 2018, Gaby Wood also draws on the Man Booker Prize archive in an article in the Times Literary Supplement, stating that: "[T] he prize had been established some months earlier [in 1968] by the publishers Tom Maschler and Graham C. Greene, with the aim of emulating the Prix Goncourt, which unfailingly stimulated the reading of - and conversation about - new fiction" (Wood, 2018). Wood's article begins with a discussion of the inaugural Prize's judges, the places where they met ("Sometimes they met at Bertorelli's restaurant in London. Once they spent a weekend together at Michael Astor's house in the Cotswolds." (Wood, 2018)) and the notes they wrote on the books they discussed (Rebecca West's typewritten notes on Michael Frayn's book, for example, described it as 'curiously dull' (Wood, 2018)). In constructing the origin of the prize, this piece of literary journalism published in 'the leading international weekly for literary culture' ('Home Page - The TLS', n.d.) draws on the people involved in creating the prize, its inaugural judges, their judgements of the initial longlist, and the aims of the prize.

Yet archives and historical timelines of literary institutions are not only useful commodities for scholars and literary journalists. The institutions themselves frequently make use of their archival assets, as Squires examines in this chapter on publishers' birthdays: "The development of the brand through anniversary publishing must include the core values of the company, which are constructed and negotiated through the company's history" (Squires, 2013: 183). In the same way, Wood reconstructs a seamless narrative of the Man Booker Prize's brand through its archive: "They found an eminently willing sponsor in Booker Brothers, once a Guyana-based colonial enterprise, then an enlightened business run by Jock Campbell, a socialist peer with a strong desire to compensate for the history with which his sugartrading ancestors had been associated" (Wood, 2018). Wood's article makes use of the history of the Booker Prize to frame the prize in a particular ideological light - and the archive materials themselves are called on to confirm how the prize dealt with the colonial origin of its wealth: "Once the prize was established, the sponsors were routinely referred to in correspondence as 'the sugar daddies"' (Wood, 2018).

However, publishers and literary awards are not the only literary institutions which hold and make use of archives. Authors also own significant documentation which, through archiving, has the potential to endure beyond their lifetime. Anna Auguscik writes about the mechanisms at play here:

Some of the least publically-available documents will only be preserved for the eyes of collectors and (future) literary historians: the author's manuscript, correspondence with the publisher and/or literary agent, proof copies, advance reader's copies and first editions. Yet increasingly, contemporary authors are giving this documentation away in their lifetimes. (...) The acquisition of an author's estate during their lifetime involves speculation on both sides - the value of the documents is not easily discernible 


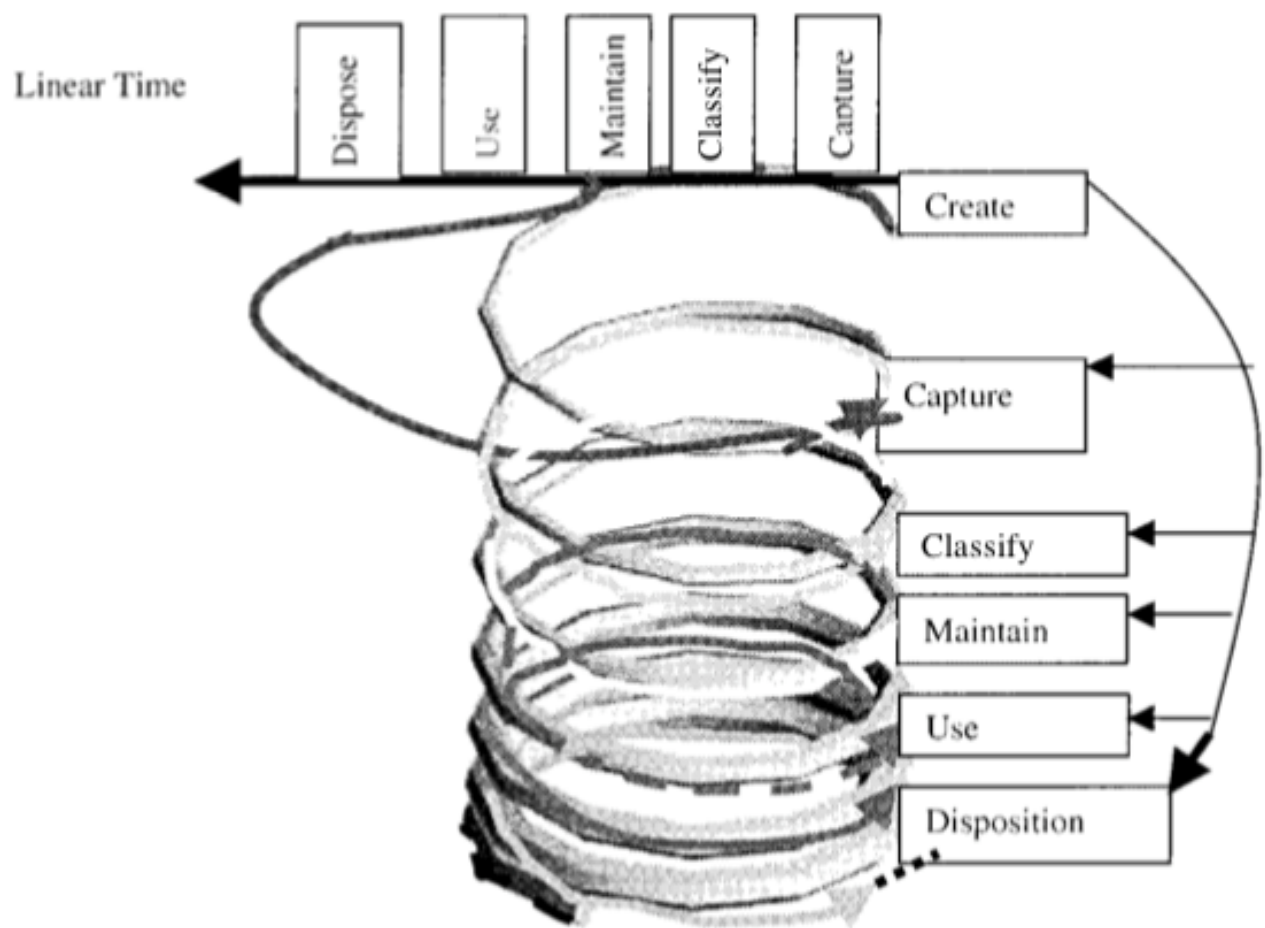

Figure 5. A Helical Model of Record Formation (Brothman, 2006: 263, Fig. 4)

by either party and could always be estimated as higher or lower than the price offered at the time of the transaction at a later point in time - but the presence of an archive also makes authors more available for academic research. (Auguscik, 2017: 72)

\section{ARCHIVES IN RECORD FORMATION}

The following section provides insight into the various ways in which archival studies as a discipline has reckoned with this issue. While the discussions of publisher and prize archives above gave the impression of fixed corpora of materials ('115 acid-free cardboard boxes' (Crace, 2003)), Walby and Larsen's research into government agencies through Access to Information defines the idea of a 'live archive':

In contrast with notions of archives and archiving that focus on the preservation and organization of a 'documentary heritage,' the idea of the live archive highlights the dynamic systems of textual production and communication unfolding in government agencies today. (Walby and Larsen, 2011: 625)

A live archive, then, involves a degree of speculation. To follow Auguscik above: just as the (monetary) value of a writer's estate is difficult to gauge before their career has run its course, so are the types of documents required to (re-)construct a history for an event that has not yet occurred. Brien Brothman describes the requirement of an end point for an archive - in my particular study, the end point is the creation of the prize - as 'the final moment,' which is being anticipated or constructed in the process of record formation:

The identity of each of the successive stages (states) of record-keeping - creation, classification, capture, arrangement and description, maintenance, preservation, and so on - also hinges on the anticipation of an ending, on the belief in a moment of closure and completeness, in which records as entities reach resolution, arrive at some final destination. Indeed, the construction of a final moment, a permanently fixed 'presentness,' is critical for giving a retrospective coherence and finiteness to each of the cycle's preceding phases. The finality of the end is an indispensable unifying moment of the model of recordkeeping. Belief in the existence of a final moment retroactively enables, indeed determines, the order, function, meaning and significance of each of the earlier phases of the story. (Brothman, 2006: 246)

Rather than seeing documents as having a fixed start and end date - creation and final deposit - Brothman's helical model of record formation, 'represent[ing] documentary temporal existence as involving departure from, and circling back toward, a point on a time line' (Brothman, 2006: 261, emphasis in original), allows for a conceptualisation of an archive's fluidity. In this model, illustrated by Figure 5, linearity and strict chronology is replaced with a loop whose trajectory travels back towards the point of creation, representing the different stages 
of a document and the multiple temporalities inherent in it. A document that is edited and altered over the course of the years, which begins its life as a private note during a meeting and ends up as a public-facing press release, for example, has many temporal points within it. In the case of my research project and the difficulty of planning the preservation of the archive of a literary award which may come to exist in the future, Brothman's model offers reassurance that the uncertainty of the award's future existence need not become an issue. Brothman argues that this 'final moment retroactively enables' (Brothman, 2006: 246) a narrative. Following this idea, it is not necessary to know from the outset which documents will be required for an archive, as the end point - whatever it may be - will retroactively determine the order of the archive's contents.

In his article on de-historicising the archive, Wolfgang Ernst also writes about the faculty of record formation to encompass multiple points in time within one document: "Let us therefore address the archive not as a coherent depository for memory supply but instead identify its multiplicity of temporal layers with and within memory technologies." (Ernst, 2016: 12) Rather than proposing a new model for record formation altogether, Ernst reads the multiplicity of time in an archive as a road to liberation through non-narrative history:

My epistemological intention is to liberate archival memory from its reductive subjection to the discourse of history and re-install it as an agency of multiple temporal poetics in its own right. (Ernst, 2016: 12)

He continues, asserting that 'the archival mode of memory (record management) is a non-narrative alternative to historiography' (Ernst, 2016: 12). What Ernst's work suggests is that archives can instead present a real, radical alternative through their ambivalence and need not necessarily be commodified and narrativised as marketing tools. Jeffrey Schnapp's work adds to this the idea that within the capacities of $21^{\text {st }}$ century archiving also lies further potential for the types of documentation they can hold:

Last but not least, this expanded sensorium of cultural memory is accompanied by new forms of capture that allow for time-scales that would have been inconceivable only a century ago: from documentation of macro-events that occur over centuries (like environmental changes) to that of micro-events that occur on the scale of seconds (viz. snapshots and tweets). (Schnapp, 2016: 18)

(Imagined) posterity and futurity are often in play in scholarship critically engaged with or describing the work with archives. Barbara McBane's work on the archive of Veronica Friedman, which was preserved after her death in the San Francisco LGBT Historical Society's collection reflects on 'the holes in the archive', which 'catapult it out of linear time, into the blurred, complicating, and asynchronous temporalities of the uncanny and the spectral' (McBane, 2013:63). McBane describes these gaps as 'progenerative (...) activat[ing] links between queers of different generations in different times and places (...) to future archive-interpreters like myself; and to the audiences of us all' (McBane, 2013: 63). McBane can see within this archive the multiple temporal links into past, present and future. The blurriness of the documents' temporalities was also apparent in the nature of the individual documents:

Some of her papers were crafted for the official record - for the archive; others were personal and spoke of the loss of home and family. (...) The two kinds of documents often bled into one another. Sometimes the official documents became very personal, and the lists turned into poems. (McBane, 2013: 59)

Collecting in the present for the future, Nicholas Samuel Fitch describes efforts to collect material in Argentina during a year studying abroad. Fitch's account shows a sense of responsibility for the future, specifically future research. Fitch writes that, due to the political and economic situation of the country, 'the great majority of the nation's immense cultural patrimony is never sufficiently collected, documented, preserved, or made accessible to the public' (Warren Davidson and Fitch, 2002: 561) and that therefore 'individual efforts toward the collection and conservation of cultural materials are vitally important if future generations are to have access to them for research' (Warren Davidson and Fitch, 2002: 561). Fitch also describes a consciousness of the future purpose of documents, even if they are not documents whose immediate impact or relevance can be determined: "Even though they are not always of direct or lasting interest to me, I am very careful to conserve such materials as political ephemera and flyers, which might otherwise disappear" (Warren Davidson and Fitch, 2002: 561). The very fact of the potential that these documents might disappear is the motivation behind Fitch's collection and preservation effort. (Incidentally, Fitch does not appear to have reflected on the ethics of such a collection effort, as the conclusion of the piece reads, "I am hoping to expand my collection significantly in the coming months, as the desperate economic situation further depresses book prices and as the peso devalues" (Warren Davidson and Fitch, 2002: 561)).

In interview with Frances Guerin, the film maker Daniel Eisenberg reflects on his work taking archive footage out of its original context. He is quoted as saying: 
We are at a very different point in the history of moving images—-where cell phones more likely produce the documents of history. I routinely trace this movement from documents produced officially to unofficial documents to our present moment, when we can see everyday revolutions being mobilized by cell phones and social media. It's a much more democratic space of image production. So the question is, what constitutes the archive today? Is it the Cloud? I don't know if this can be answered, except in the use of images. In the end, the archive is constituted by what is and isn't used, what is and isn't saved, and by whom. It's for others to define somewhere down the line. (Guerin, 2012: 115)

This is a practical application of Brothman's helical model of record formation; the definition of the archive can happen retrospectively.

The artist Julie Bacon reflects on artists' use of archive in their work. "Discourse in the academy - from sociology, feminism, postmodernism and postcolonial theory through to the linguistic strategies of poststructuralism and cultural studies - has created a groundswell of enquiry into history making, identity and representation. This considers how territory is claimed through the power of language, knowledge and the physical occupation of space." (Bacon, 2007: 52) This makes visible the political act of claiming territory through the archiving of a new potential prize whose creation is rooted in feminist practice and feminist research. Veronica Hollinger (Hollinger, 2010) discusses in Science Fiction (SF) studies the idea of writing a history of all imagined futures within SF literature. Hollinger quotes Mark Currie, who argues (following Derrida) that 'archive fever' is 'a future orientation, or a mode of interpretation, which structures the present' (Currie, 2007:11, qtd in Hollinger, 2010:30); contemporary culture is 'increasingly conscious of its own present as the object of a future memory' (Currie, 2007:27, qtd in Hollinger, 2010: 30).

While this discussion is about a type of literature and therefore may seem out of place in an article in publishing studies, the lens on archives is particularly relevant to the type of future consciousness my own work, Eisenberg's and Fitch's statements invoke. The potential longevity of documents - their potential survival - is only relevant through this consciousness of the present as the past memories of the future. This future-directed consciousness of 'present as the object of a future memory' structures and informs speculative choices about preservation and collection in the present.

What do archives mean to feminist research? As Cifor and Wood write in their 2017 article on Critical Feminism in the Archives: "Archives have the potential to work towards dismantling the heteronormative, capitalist, racist patriarchy on many fronts and through many avenues" (Cifor and Wood, 2017: 2). They also reflect on 'what Ann Laura Stoler describes as 'epistemological skepticism", a focus on "history as narrative, and on history-writing as a charged political act' (Stoler, 2002: 92, qtd in Cifor and Wood, 2017: 14). Cifor and Wood elaborate on this, arguing that: "Rather than conceiving of the archives as a neutral space within which historical materials were housed and from which the writing of history emerged, [the archive] itself becomes an object worthy of scrutiny and theorization" (Cifor and Wood, 2017: 14). This, in line with Bacon's work above, reframes the writing of history and the making of an archive as a deliberate, political act of 'claiming territory', and invites the archivist to denaturalise the set of discourses that make up the archival structure. Cifor and Wood make this territory-claiming work visible:

By employing the methodology of feminist historiography, we simultaneously provide rich context for narratives and counter-narratives while necessarily always turning analysis back on our own process. We are self-consciously engaged in a kind of history making about history makers who conceived of their interventions as vital correctives to standard historical practices. (Cifor and Wood, 2017: 3)

As Gifford and McMillan (1997), Christianson \& Lumsden (2000) and Norquay (2012) and Marsden (2019) have shown, Scottish women writers have been largely absent from the historical record of Scotland's national literature. This nascent archive of a prize which may never come to be will match in form and intention the redressing and resisting of this absence, as Cifor \& Wood assert: “These archival impulses represent a larger pattern of techniques of self- representation which themselves formed a broader project of resisting the marked absence of minoritized populations from the historical record" (Cifor and Wood, 2017: 5).

\section{CONCLUSION}

What, then, is the consequence of these reflections for this kind of live embedded award scholarship? Firstly, this article has shown that the collaboration model is more complex than anticipated, partly due to the project's nature as a live contemporary study that actively works towards future transformative impact. This requires a rethinking not only of the positionality of the researcher but of the nature of the documents used and created as part of the research process. 
Secondly, in order to aid this rethinking, these types of projects ought to draw more on scholarship in other fields such as feminist research methodology, record formation, archival studies, and science fiction studies. Collaboration with industry on this new type of prize research relies on other prize research, but until now, publishing's understanding of prize archives has been insufficient for charting the responsibility and possibilities for this archive. Drawing on a clear understanding of the embedded feminist researcher and the concepts of record formation, this article has demonstrated that collaborative research is messy and nonlinear, and that the helical model of record formation, along with science fiction's understanding of the present as holding potentiality for the future is a good starting point for thinking about the speculative archive.

Finally, a pragmatic outcome from this article has been the realisation that the future archive of the potential future literary award will have no shortage of documents. Future scholars of the Scottish Women Writers Prize (working title) will be able to draw on a rich and varied archive of meeting notes, email correspondence, interview transcripts, as well as Tweets and Facebook comments. Applying the helical model of record formation to this particular case takes away the pressure of creating 'completed' documents, instead reconfiguring the archiving process as not linear but as a loop, and not thinking of the archive as fixed but as living and moving. I cannot know what future archivists will value, so I feel a responsibility to collect as much as possible, and hold on to my triple position as insider, outsider, and 'speculative archivist.' What is a speculative archivist? A speculative archivist describes a researcher who is actively engaged in collecting documents towards a future purpose. The speculative archivist need not know what the purpose of the document collection is. The speculative archivist should resist the urge to narrativise the documents they have access to, resist the desire to set a key starting or end date to the formation of their records, and embrace a fluid, porous, shifting set of temporalities inherent in their work. Understanding the political and social responsibility of a feminist speculative archivist means understanding that the archive holds the potential to rewrite women into history; specifically, that this particular speculative archive can add to other scholars' and activists' efforts to rewrite Scotland's national literary history.

\section{REFERENCES}

Armstrong, C. (2018, May 9). Interview by Christina Neuwirth.

Auguscik, A. (2017). Prizing Debate. The Fourth Decade of the Booker Prize and the Contemporary Novel in the UK, 1st Edition. Bielefeld: transcript. https://doi.org/10.14361/9783839438534

Bacon, J. (2007). Archive, Archive, Archive! Circa, 111, 50-59. https://doi.org/10.2307/25564523

Barton, B. (2011). My Auto/Ethnographic Dilemma: Who Owns the Story? Qualitative Sociology, 34, 431-445. https://doi.org/10.1007/s11133-011-9197-x

Brothman, B. (2006). Archives, Life Cycles, and Death Wishes: A Helical Model of Record Formation. Archivaria, 61(0), 235-269.

Calder, J. (2018, April 25). Interview by Christina Neuwirth.

Christianson, A. and Lumsden, A. (2000b). Introduction, in A. Christianson \& A. Lumsden (eds), Contemporary Scottish women writers (pp. 1-7). Edinburgh: Edinburgh University Press.

Christianson, A. and Lumsden, A. eds. (2000a). Contemporary Scottish women writers. Edinburgh: Edinburgh University Press.

Cifor, M. and Wood, S. (2017). Critical Feminism in the Archives. Journal of Critical Library and Information Studies, 1(2). https://doi.org/10.24242/jclis.v1i2.27

Crace, J. (2003). Oxford Brookes nabs Booker archive. The Guardian, 2 September. Available at: https://www.theguardian.com/books/2003/sep/02/bookerprize2003.highereducation (Accessed 22 January 2019).

Currie, M. (2007). About Time: Narrative, Fiction and the Philosopby of Time. Edinburgh: Edinburgh University Press.

English, J. F. (2002). Winning the Culture Game: Prizes, Awards and the Rules of Art. New Literary History, 33(1), 109-135. https://doi.org/10.1353/nlh.2002.0005

Ernst, W. (2016). Radically De-Historicising the Archive. Decolonising Archival Memory from the Supremacy of Historical Discourse, in N. Petrešin-Bachelez \& R. Ištok (eds), Decolonising Archives (pp. 9-16).

L'Internationale Online.

Gifford, D. and McMillan, D. (1997b). Introduction: A History of Scottish Women's Writing, in D. Gifford and D. McMillan (eds), A History of Scottish Women's Writing (pp. ix-xxiii). Edinburgh: Edinburgh University Press.

Gifford, D. and McMillan, D. eds. (1997a). A History of Scottish Women's Writing. Edinburgh: Edinburgh University Press.

Guerin, F. (2012). Archives and Images as Repositories of Time, Language and Forms from the Past: a Conversation with Daniel Eisenberg. The Moving Image: The Journal of the Association of Moving Image Archivists, 12(1), 112-118. https://doi.org/10.1353/mov.2012.0025 
Hesse-Biber, S. N. (2007). The practice of feminist in-depth interviewing, in S. N. Hesse-Biber and P. L. Leavy, Feminist Research Practice (pp. 111-147). Available at: https://us.corwin.com/sites/default/files/upmbinaries/12937_Chapter5.pdf (Accessed 11 April 2018).

Hesse-Biber, S. N. (2013). A Re-Invitation to Feminist Research, in S. N. Hesse-Biber (ed), Feminist Research Practice: A Primer, $2^{\text {nd }}$ Edition (pp. 1-13). Thousand Oaks, California: SAGE Publications.

Hollinger, V. (2010). A History of the Future: Notes for an Archive. Science Fiction Studies, 37(1), 23-33.

Home Page - The TLS. (n.d.).The Times Literary Supplement. Available at: https://www.the-tls.co.uk/ (Accessed 19 January 2019).

Literary Awards. (n.d.). Saltire Society. Available at: http://www.saltiresociety.org.uk/awards/literature/literaryawards/ (Accessed 18 April 2019).

Marsden, S. (2016). The Saltire Society Literary Awards, 1936-2015: A Cultural History (Doctor of Philosophy in Publishing Studies). University of Stirling, Stirling.

Marsden, S. (2019). Why Women Don't Win Literary Awards: The Saltire Society Literary Awards and Implicit Stereotyping. Women: A Cultural Review, 30(1), 43-65. https://doi.org/10.1080/09574042.2018.1561047

Marsden, S., \& Squires, C. (2019). The First Rule of Judging Club...: Inside the Saltire Society Literary Awards. Journal of Cultural Analysis and Social Change, Forthcoming.

McBane, B. (2013). Veronica's Ghost: Queer Time and the Porous Archive. Art Journal, 72(2), 58-63. https://doi.org/10.1080/00043249.2013.10791033

McDowell, L. (2018, May 8). Interview by Christina Neuwirth.

Moir, J. (2018, May 23). Interview by Christina Neuwirth.

Neuwirth, C. (2018, September 12). Gender (in)equality in Scottish publishing: a path to qualitative and quantitative evidence. Presented at the CAMEo Conference 2018, Care in the Media and Cultural Industries, University of Leicester.

Norquay, G. (2012a). Introduction, in G. Norquay (ed), The Edinburgh Companion to Scottish Women's Writing (pp. 110). Edinburgh: Edinburgh University Press.

Norquay, G. ed. (2012b). The Edinburgh Companion to Scottish Women's Writing. Edinburgh: Edinburgh University Press.

Oakley, A. (1981). Interviewing Women: A Contradiction in Terms, in H. Roberts (ed), Doing Feminist Research (pp. 30-61). Available at: http://www.brown.uk.com/teaching/HEST5001/oakley4.pdf

Oliver, M. (2018, May 8). Interview by Christin Neuwirth.

Puwar, N. (1997). Reflections on Interviewing Women MPs. Sociological Research Online, 2(1). Available at: from http://www.socresonline.org.uk/2/1/4.html (Accessed 11 April 2018).

Reid, K. (2018). Meet ROAR. Glasgow Women's Library. Available at: https:/ /womenslibrary.org.uk/ 2018/08/16/meet-roar/ (Accessed 18 April 2019).

Schnapp, J. (2016). Buried (and) Alive, in N. Petrešin-Bachelez \& R. Ištok (eds), Decolonising Archives (pp. 17-22). L'Internationale Online.

Scottish Graduate School for Arts \& Humanities. (n.d.). Available at: http:/ /www.sgsah.ac.uk/ funding/ ces/\#/eligibility (Accessed 5 June 2018).

Shah, A. (2018, May 16). Interview by Christina Neuwirth.

Squires, C. (2004). A Common Ground? Book Prize Culture in Europe. The Public, 11(4), 37-48. https://doi.org/10.1080/13183222.2004.11008866

Squires, C. (2013). Happy Birthday! Publishers' Anniversaries, Celebration, Commemoration, and Commodification, in W. Wootten \& G. Donaldson (eds), Reading Penguin: A Critical Anthology (pp. 171-188). Newcastle upon Tyne: Cambridge Scholars Publishing.

Squires, C. (2018, May 11). Interview by Christina Neuwirth.

Squires, C., Reeder, E., Armstrong, C., \& Shah, A. (2017, May 31). Creative Economies Studentships Application Form 2017, Women of Words: Gender Equality in Contemporary Scottish Writing and Publishing. Retrieved from Private.

Stoler, A. L. (2002). Colonial Archives and Arts of Governance. Archival Science, 2, 87-109. https://doi.org/10.1007/BF02435632

Walby, K., \& Larsen, M. (2011). Getting at the Live Archive: On Access to Information Research in Canada*. Canadian Journal of Law \& Society / La Revue Canadienne Droit et Société, 26(3), 623-633. https://doi.org/10.3138/cjls.26.3.623.

Warren Davidson, R. and Fitch, N. S. (2002). Una Locura Argentina. The Elmer Adler Book Collecting Prize. The Princeton University Library Chronicle, 63(3), 559-564. https://doi.org/10.25290/prinunivlibrchro.63.3.0559

Wood, G. (2018). For the taking: Notes from the Man Booker Prize archive. TLS. Times Literary Supplement, (6014), 17. 